\title{
A New Approach of Measuring Earnings Quality in Islamic Banks
}

\section{Khaled Aljifri ${ }^{1 *}$ and Sunil Kumar Khandelwal ${ }^{2}$}

${ }^{1}$ College of Business and Economics, United Arab Emirates University, UAE

${ }^{2}$ Regional Head, Tagetik Middle East

The developments that have taken place in Islamic banking are need-based and not planned or structured, as is necessarily the case because there is no central body to oversee the growth of business. This has given rise to several inconsistencies and issues affecting the quality of Islamic banking. One of the main concerns is the strictness with which the rules of Shariah are applied. The way in which products are structured and marketed may possibly have an impact on the quality of earnings generated by Islamic banks. Despite its importance, this has been one of the most neglected areas in the literature on Islamic finance.

There are a number of studies on the efficiency and profitability of Islamic Banks [1-7]. However, an important dimension which has been neglected in the literature is the earnings quality of Islamic banking, especially insofar as quality relates to core Islamic financial contracts (products). Some researchers define earnings quality as "the absence of earnings management" [8]; others determine earnings quality from the perspective of those who use financial reports, judging quality by the reliability and relevance of financial reporting [9]. Different approaches have been used to measure earnings quality in earlier studies, including accruals quality, abnormal accruals, and earnings variability [10-12].

This paper presents a new approach that can be used to measure earnings quality of Islamic banks. The approach is based on a measure of the pureness and use of core Islamic financial contracts (products), which implies the strictness of adherence to Shariah principles in contracts. The approach considers the values and principles of Islamic banks and extends the meaning of earning quality to cover not only "absence of earnings management" and "reliability and relevance" but also cover the question of meeting certain specific standards (i.e., the level of strictness of compliance with Shariah law in contracts). Unlike conventional banks, Shariah rules in Islamic banks add an ethical dimension to relationships and introduce a concept of trusteeship and a greater role in meeting the needs of society and mankind. Aljifri and Khandelwal [13] explain that, "Contracts in conventional financial systems are purely drawn and based on material information, facts and conditions, whereas the contracts in the Islamic financial system are made of material and ethical components".

The new approach suggests the construction of an index that outlines the relevant components of items presented in income statements. A content analysis is needed to reveal the structure of Islamic contracts (products) used by an Islamic bank for which earnings quality can be determined and evaluated. Islamic financial contracts can be classified into "Risk Shifting Contracts" (i.e., Murãbaha, Salam and Ijãrah) and "Risk Sharing Contracts" (i.e., Mushãrakah and Mudãrabah). Risk sharing contracts are considered to have a higher level of Shariah acceptance compared to risk shifting contracts. However, a number of studies show that risk shifting contracts are the ones that are commonly used by Islamic banks [14-17]. These contracts are attractive to banks because they are based on a cost-plus financial system which involves fewer risks compared to risk sharing contracts. When evaluating earnings quality, credit should be given to an Islamic bank that derives its main sources of earnings from risk sharing contracts. This is because these contracts are considered to be more fully Shariah-compliant, where profits and losses are distributed more equally. The goal of risk sharing contracts is to achieve socio-economic justice which is one of the main values in Islamic principles.

This paper has made the first step by proposing a new approach to measuring earnings quality in Islamic banks. The paper contributes to the literature in the following ways:

(1) It introduces a new approach for measuring earnings quality in Islamic banks, and

(2) It explores the relationship between earnings quality and Islamic contracts (products).

This paper may serve to motivate policy makers, investors, customers, and others, to examine further the success of Islamic banks. The new approach raises the following question: Would including the dimension of Shariah compliance in measuring earnings quality increase confidence in Islamic banks, and would this in turn help this sector to have greater sustainability of earnings?

\section{References}

1. Haron S (2004) Determinants of Islamic Bank Profitability. Global Journal of Finance and Economics 1: 2-18.

2. Alkassim F (2005) The Profitability of Islamic and Conventional Banking in the GCC Countries: A Comparative Study 11: 48-54

3. Srairi S (2009) A comparison of the profitability of Islamic and conventional banks: The case of GCC countries Bankers, Markets and Investors 98: 16-27.

4. Obeid H, Moussawi C (2010) Evaluating the Productive Efficiency of Islamic Banking in GCC: A Non Parametric Approach. International Research Journal of Finance and Economics 53: 178-190.

5. Akhtar MF Ali K, Sadaqat S (2011) Factors Influencing the Profitability of Islamic Banks of Pakistan. International Research Journal of Finance and Economics 66: 125-132.

6. Qureshi M, Shaikh M (2012) Efficiency of Islamic and Conventional Banks in Pakistan: A Non-parametric Approach. International Journal of Business and Management 7: 40-50

7. Noor M (2012) The Determinants of Efficiency of Islamic Banks. The IUP Journal of Bank Management 11: 32-70.

8. Ismail WA, Dunstan K, Van Zij T (2010) Earnings quality and corporate governance following the implementation of Malaysian code of corporate governance.

9. Zainuldin MH (2012) Earnings Quality in Financial Institutions: A Comparative Study of Islamic Banks and Conventional Banks. Int. J. Of Integrated Engineering.

10. Dechow PM, Dichev ID (2002) The quality of accruals and earnings: the role of accrual estimation errors. The Accounting Review 77: 35-59.

*Corresponding author: Khaled Aljifri, College of Business \& Economics, United Arab Emirates University, UAE, Tel: +971-3-7673333; E-mail: K.Aljifri@uaeu.ac.ae

Received November 10, 2014; Accepted November 10, 2014; Published November 17, 2014

Citation: Aljifri K, Khandelwal SK (2014) A New Approach of Measuring Earnings Quality in Islamic Banks. J Account Mark 3: 117. doi: 10.4172/2168-9601.1000117

Copyright: (c) 2014 Aljifri K, et al. This is an open-access article distributed under the terms of the Creative Commons Attribution License, which permits unrestricted use, distribution, and reproduction in any medium, provided the original author and source are credited. 
Citation: Aljifri K, Khandelwal SK (2014) A New Approach of Measuring Earnings Quality in Islamic Banks. J Account Mark 3: 117. doi: 10.4172/21689601.1000117

11. Dichev ID, Tang VW (2009) Earnings volatility and earnings predictability. Journal of Accounting and Economics 47: 160-181.

12. Dichev ID, Tang VW (2008) Matching and the changing properties of accounting earnings over the last 40 years. The Accounting Review 83: 1425-1460.

13. Aljifri K, Khandelwal S (2013) Financial Contracts in Conventional and Islamic Financial Institutions: An Agency Theory Perspective. Review of Business \& Finance Studies 4: 79-88.

14. Aggarwal R, Yousef $T$ (2000) Islamic Banks and Investment Financing, Journal of Money, Credit and Banking 32: 93-120.
15. Archer S, Ahmed T (2003) Emerging Standards for Islamic Financial Institutions: the Case of the Accounting and Auditing Organization for Islamic Financial Institutions. The World Bank, Washington, D.C, USA

16. Chong BS, Liu MH (2009) Islamic banking: Interest-free or interest-based? Journal of Pacific-Basin Finance 17: 125-144.

17. Ascarya $H$ (2011) The Lack of profit-and-loss sharing financing in Indonesia's Islamic banks revisited. 